\title{
Meta-Analisis Pengaruh Penerapan Pendekatan Saintifik Berbantuan Komik Terhadap Hasil Belajar IPA Siswa SMP
}

\author{
Jannatul Aulia ${ }^{1}$, Niki Dian Permana $\mathbf{P}^{2}$, Zarkasih ${ }^{3}$, Theresia Lidya Nova ${ }^{4}$ \\ 1,2,3,4 Program Studi Tadris IPA, Universitas Islam Negeri Sultan Syarif Kasim Riau \\ e-mail: \\ 1 jannatul.auliaa@students.uin-suska.ac.id \\ 2niki.dian.permana@uin-suska.ac.id \\ 3zarkasih@uin-suska.ac.id \\ theresia.lidya.nova@uin-suska.ac.id
}

\begin{abstract}
.
The purpose of this study is to conduct an analytical study of the application of scientific media-assisted application of science learning outcomes to junior high school students. This research uses a meta-analysis method. The meta-analysis is the result of the analysis of articles from national journals that have been accredited in Sprott 1 to Sprott 4 which have study topics related to science and communication media in science learning as many as 15 journal articles. Based on the results of data analysis obtained from the results of research using scientific aided communication media can improve learning outcomes, scientific thinking skills, increase students' creative thinking skills and effectively improve student literacy.
\end{abstract}

Keywords: meta-analysis, scientific registration, comic media.

\begin{abstract}
ABSTRAK.
Tujuan penelitian ini adalah untuk melakukan studi analisis tentang pengaruh penerapan pendekatan saintifik berbantuan media komik terhadap hasil belajar IPA pada siswa SMP. Penelitian ini menggunakan metode meta-analisis. Meta-analisis merupakan hasil analisis dari artikel-artikel dari jurnal nasional yang sudah terakreditasi pada sinta 1 hingga sinta 4 yang memiliki topik kajian berkaitan dengan pendekatan saintifik dan media komik dalam pembelajaran IPA sebanyak 15 artikel jurnal. Berdasarkan hasil analisis data didapatkan hasil bahwa penerapan pendekatan saintifik berbantuan media komik dapat meningkatkan hasil belajar, keterampilan berpikir ilmiah, meningkatkan keterampilan berpikir kreatif siswa dan efektif meningkatkan literasi sains siswa.
\end{abstract}

Kata kunci: meta-analisis, pendekatan saintifik, media komik.

\section{PENDAHULUAN}

Menurut undang-undang nomor 20 tahun 2003 tentang Sistem Pendidikan Nasional, pendidikan bertujuan untuk mengembangkan potensi peserta didik agar menjadi manusia yang beriman dan bertakwa kepada Tuhan Yang Maha Esa, berakhlak mulia, sehat, berilmu, cakap, kreatif, mandiri, dan menjadi warga negara yang demokratis serta bertanggung jawab. Berdasarkan hal tersebut, maka pendidik tidak hanya sekedar memberikan ilmu, namun juga harus membentuk 
karakter-karakter siswa yang sesuai dengan undang-undang tersebut, guna menjadi jati diri bangsa ini.

Berdasarkan pernyataan di atas dapat dilihat bahwa penentu keberhasilan belajar siswa adalah guru yang merupakan pendidik. Guru dapat menggunakan berbagai cara dalam mendidik siswa diantaranya menggunakan metode yang variatif, media yang mendukung maupun pendekatan yang efektif. Terdapat banyak sekali bentuk-bentuk model dan pendekatan yang dapat diterapkan oleh guru supaya materi yang disampaikan dapat dengan mudah diterima sehingga dapat meningkatkan kemampuaan berpikir siswa.

Menurut Permatasari (2014) untuk meningkatkan kemampuan siswa, maka guru harus melakukan pembelajaran yang terstruktur secara tahapan dan terukur secara optimal. Tahapan yang terstruktur itu adalah tahapan yang dilakukan mulai dari tahap yang paling mudah hingga ketahap yang paling sulit. Seluruh langkah tersebut dilakukan agar dapat diukur tinkat pencapaian peserta didik. Hal ini berlaku terhadap seluruh pembelajaran, termasuk juga pelajaran Ilmu Pengetahuan Alam (IPA) yang mecakup pelajaran biologi, fisika, kimia, astronomi dan geologi. Salah satu pembelajaran yang dilakukan secara bertahap dan sesuai dengan prinsip di atas ialah dengan menggunakan pendekatan siantifik.

Implikasinya pada pembelajaran fisika ialah guru harus memberikan kesempatan kepada siswa untuk aktif berpikir dalam berbagai kegiatan pembelajaran. Ahli berpendapat bahwa konsep akan timbul pada seseorang setelah ia mengaitkan fakta-fakta atau memberikan pola fakta-fakta yang diamatinya sehingga dapat mengembangkan kemampuan menganalisis, bernalar, dan memecahkan masalah berdasarkan pengetahuan atau konsep yang telah dibangun oleh siswa sendiri. Berdasarkan teori-teori tersebut dapat disimpulkan bahwa siswa tidak hanya dijadikan objek dengan beban hafalan berbagai macam konsep dan rumus, tapi harus dijadikan subjek yang aktif dalam pembelajaran.

Pada kurikulum 2013 pembelajaran pada seluruh jenjang pendidikan seharusnya dilaksanakan dengan menggunakan pendekatan saintifik karena pendekatan tersebut membuat pembelajaran menjadi berpusat pada peserta didik. Adapun ciri atau kriteria dari pendekatan saintifik tersebut adalah Pertama, materi pembelajaran tersebut berbasis fakta dan dapat diterima nalar dan logika bukanlah hayalan, mitos ataupun legenda. Kedua, respon siswa dalam pembelajaran terhadap guru yang memberikan materi dan proses interaksi siswa dengan guru dan penjelasan guru kepada siswa sebaiknya tidak ada salah paham ataupun prasangka yang menyimpang. Ketiga, mendorong, memotivasi siswa serta menginspirasi peserta didik agar berpikir secara kritis,analistis dan tepat dalam mengidentifikasi, memahami, memecahkan suatu masalah dan mengaplikasikan materi pembelajaran kedalam kehidupan sehari-hari. Keempat, memotivasi peserta didik agar mampu berpikir hipotetik dalam melihat perbedaan,kesamaan ataupun hubungan anatara satu dengan yag lain pada materi pembelajaran. Kelima, mendorong peserta didik agar mampu memahami dan menerapkan serta mengembangkan pola berpikir yang rasional dan objektif dalam merespom materi pembelajaran. Keenam, pembelajaran berbasis konsep, teori dan fakta empiris yang dapat dipertanggungjawabkan.dan yang terakhir ialah tujuan dari pembelajaran dengan menggunakan pendekatan saintifik ialah pembelajaran tersebut haruslah dirumuskan secara sederhana, jelas namun tetap menarik peserta didik dalam belajar. (Wijayanti, 2014)

Penggunaan media pembelajaran juga merupakan sarana yang dapat digunakan sebagai perantara dalam proses pembelajaran agar mudah dalam penyampaian materi. Hal ini tentu sejalan dengan tujuan pembelajaran dan kriteria dari pendekatan saintifik di atas. Media pembelajaran yang efektif tidaklah dilihat dari harganya yang mahal ataupun murah juga tidak dilihat dari banyaknya frekuensi dari penggunaan media tersebut, namun media akan dikatakan efektif jika sesuai dengan karakteristik materi yang disampaikan, serta sesuai dengan tahap perkembangan anak. Berdasarkan ciri-ciri yang sudah disebutkan, media komik dapat dikatakan efektif dan sesuai dengan tahap perkembangan dan bisa dijadikan alternatif media pembelajaran pada jenjang pendidikan dasar dan 
menengah bahkan tidak menutup kemungkinan untuk jenjang pendidikan yang lebih tinggi, karena banyak peserta didik yang suka membaca komik.

Komik tidak hanya menawarkan alur cerita yang membuat pembaca tertarik membacanya, namun eksperesi yang ditampilkan dalam komik tersebut juga membuat pembaca terlibat secara emosional dan tertarik untuk membaca komik tersebuthingga selesai. Tentu saja hal ini membantu guru untuk meningkatkan minat baca dan literasi siswa tersebut. Melalui komik banyak nilai-nilai moral yang dapat diambil oleh pembaca melalui karakter-karakter yang ada di dalamnya. Hal inilah yang membuat komik banyak digandrungi oleh orang, tak hanya anak-anak saja yang menyukai komik, namun orang dewasa juga banyak yang membacanya karena tertarik akan isi dan ekspresi yang ditampilkan oleh karakter-karakter yang ada di dalam komik.

Komik sendiri bisa memotivasi orang untuk membaca dan menjadi sumber imajinasi. Setiap komik memberikan alur cerita yang menarik untuk diikuti, terlebih dengan karakter-karakter yang unik, panel-panel dengan teks ysng menarik untuk terus dibaca. Gambar-gambar komik pada umumnya sudah dapat menyampaikan maksud yang ingin disampaikan penulis melalui deretan gambar yang berisi alur cerita.

Memanfaatkan media komik dalam proses pembelajaran sangat penting untuk dilakukan agar pembelajaran menjadi lebih menarik dan minat baca siswa menjadi lebih meningkat sehingga dengan sendirinya tujuan pembelajaran dapat berhasil meningkatkan hasil belajar siswa terutama dalam pembelajaran IPA. Pembelajaran IPA memiliki ciri khusus yang berbeda dengan pembelajaran bidang studi lain karena dalam pembelajaran IPA terdapat materi yang tidak dapat disajikan secara langsung didepan siswa akibat adanya keterbatasan ruang dan waktu misalnya menghadirkan benda atau makhluk yang besar ke depan kelas ataupun sebaliknya dimana kita tidak bisa menghadirkan benda-benda yang mikroskopis ke hadapan siswa saat proses pembelajaran berlangsung sehingga media gambar pada komik dapat menjadi solusi untuk mengatasi masalah tersebut.

Oleh karena itu, pengintegrasian media komik dalam proses pembelajaran yang menerapkan pendekatan saintifik menjadi hal baru yang harus dianalisis dan diteliti lebih lanjut melalui penelusuran hasil-hasil kajian dan penelitian terdahulu yang pernah dilakukan sehingga dapat diperoleh kesimpulan yang tepat terkait penerapan pendekatan saintifik berbantuan media komik untuk meningkatkan hasil belajar IPA siswa.

\section{METODOLOGI}

Metode yang digunakan pada penelitian ini adalah metode SLR (Systematic Literature Review). Metode ini penelitian dilakukan dengan mengidentifikasi, mengkaji, mengevaluasi dan menafsirkan semua penelitian yang tersedia. Dengan metode ini peneliti melakukan review dan mengidentifikasi jurnal-jurnal secara sistematis yang pada setiap prosesnya mengikuti langkah-langkah atau protokol yang telah ditetapkan. (Triandini, 2019).

Sebagaimana tahapan-tahapan di atas maka penelitian ini menetapkan untuk mencari artikel jurnal yang berkaitan dengan penerapan pendekatan saintifik dan penggunaan media komik pada pembelajaran IPA. Pengumpulan data dilakukan dengan teknik dokumentasi dimana semua artikel yang diperoleh didokumentasikan pada laporan penelitian ini. Artikel yang digunakan pada penelitian ini sebanyak 15 artikel jurnal nasional terakreditasi pada sinta 1 hingga sinta 4 yang diperoleh dari google scholar. Artikel yang dipilih adalah artikel yang memiliki penelitian yang sama lalu artikel dianalisis dan dirangkum hasil-hasil penelitian tersebut kedalam satu pembahasan yang ada pada artikel ini. 


\section{TEMUAN DAN PEMBAHASAN}

Berdasarkan hasil analisis didapatkan bahwa pendekatan saintifik dikatakan efektif untuk melatih literasi saintifik peserta didik, meningkatkan keterampilan berpikir ilmiah, serta meningkatkan hasil belajar siswa dalam pembelajaran, sebagaimana hasil dari penelitian Wijayanti (2014) yang menyimpulkan bahwa setiap aspek keterampilan berpikir ilmiah mahasiswa mengalami peningkatan. Secara keseluruhan peningkatan (gain) keterampilan berpikir ilmiah sebesar 0,86 dengan kriteria tinggi.

Tidak hanya sekedar meningkatkan keterampilan berpikir ilmiah, pendekatan saintifik juga dapat meningkatkan keterampilan proses sains siswa. Hal ini dibuktikan dengan penelitian Johari Marjan \& dkk. (2014) yang meneliti pengaruh pendekatan saintiifik terhadap hasil belajar Biologi, khususnya terhadap keterampilan proses sains. Uji coba yang dilakukan mendapatkan hasil bahwa terdapat perbedaan hasil belajar antara siswa yang mengikuti pembelajaran dengan penerapan pendekatan saintifik dengan hasil siswa dari model pembelajaran langsung. Perbedaan hasil belajar Biologi antara siswa yang mengikuti pembelajaran pendekatan saintifik dengan siswa yang mengikuti model pembelajaran langsung yaitu $(F=70,630 ; \mathrm{P}<0,05)$. Perbedaan keterampilan proses sains antara siswa yang mengikuti pembelajaran saintifik dengan siswa yang mengikuti model pembelajaran langsung yaitu $(\mathrm{F}=13,013 ; \mathrm{P}<0,05)$. Berdasarkan hasil yang disebutkan, dapat disimpulkan bahwa pembelajaran dengan pendekatan saintifik lebih baik daripada model pembelajaran langsung dalam hal meningkatkan proses hasil belajar dan keterampilan proses sains siswa.

Sejalan dengan penelitian tersebut, Adib Rifqi (2019) menunjukkan keefektifan pendekatan saintifik dalam pembelajaran Biologi berorientasikan literasi saintifik dengan kategori sedang dimana nilainya 0,548 sehingga menjadikan pendekatan saintifik sebagai model terbaik untuk digunakan dalam pembelajaran Ilmu Pengetahuan Alam. Selain itu, Linda Aprilia dan Sri Mulyani (2014) menyatakan bahwa pembelajaran dengan pendekatan saintifik berpengaruh positif terhadap hasil belajar siswa. Ini dibuktikan dengan peningkatan hasil nilai rata-rata pretest 67 menjadi 84 saat posttest. Hasil ini tentu menguatkan pengungkapan Johari Marjan (2014) bahwa pendekatan saintifik efektif dalam meningkatkan hasil belajar tiap aspek kognitif siswa pada jenjang pengetahuan, pemahaman, dan penerapan.

Sukini (2019) menyatakan bahwa, penerapan pendekatan saintifik yang dibelajarkan kepada siswa membuat siswa lebih aktif dan menunjukkan hasil belajar yang baik, dimana terjadi peningkatan hasil belajar siswa yang sangat nyata. Hal tersebut dikarenakan pendekatan saintifik memiliki keunggulan dalam mengaktifkan dan meningkatkan hasil belajar siswa. Tak hanya itu dalam penelitian Hendra Erik R (2014) pendekatan saintifik juga meningkatkan kemampuan berpikir kreatif siswa hal ini dibuktikan dengan tercapainya nilai rata-rata siswa sebesar 71,55 dan mencapai ketuntasan.

Komik sebagai media pembelajaran sudah banyak digunakan mulai dari taman kanak-kanak hingga ke jenjang SMA. Komik sebagai media pembelajaran dapat mengurangi kebosanan dalam belajar karena selama ini pembelajaran banyak dilakukan hanya dengan menyampaikan materi dan teori serta metode yang dilakukan hanyalah metode ceramah yang semakin membuat siswa bosan dengan materi yang diajarkan. Penggunaan komik di beberapa sekolah malah sudah terbukti dapat meningkatkan rata-rata hasil tes.

Menurut penelitian Devy Indah Lestari \& dkk. (2016) dalam Jurnal Inovasi Pendidikan IPA yang sudah terindex Scopus menunjukkan media pembelajaran IPA berbentuk komik memiliki karakteristik dan memuat indikator berpikir analitis sehingga layak digunakan dan efektif untuk meningkatkan kemampuan berpikir analitis dan sikap ilmiah siswa. Siswa juga setuju jika komik sains ataupun komik IPA membantu mereka dalam memahami konsep IPA dan mengurangi kesalahpahaman dalam materi yang abstrak. Hal ini sesuai dengan pernyataan Nelah Roswati \& dkk. (2019) yang menyatakan dalam penelitiannya: "The result shows, most of the students agreed that science comic 
book helps them to learn through simplifying science concept and understanding the topic more accessible. The ideal science comic should also follow the right steps, appropriate aspects consisted, gain more science experience for both students and teachers to enjoy the learning process". Hal ini juga diperkuat oleh penelitian dari Niswatul Khoiriyah \& dkk. (2019) dalam artikel Development comics Physics Education With STEM for Simulating Straight Line Motiom Concept Mastery in Junior Hight School Students. Menurut Khoiriyah, pembelajaran fisika lebih efektif dibantu dengan komik fisika sesuai dengan hasil yang didapat oleh peneliti bahwa ketertarikan (attractiveness) siswa terhadap komik diperoleh nilai rata-rata 3,38 dan kemudahan (convenience) dalam belajar diperoleh nilai 3,38.

Lailatul Aslamiyah \& dkk. (2017) menyatakan bahwa media komik dinyatakan layak sebagai media oleh ahli materi dan ahli media. Tanggapan siswa terhadap media komik juga baik karena dianggap mudah dipahami dan lebih menarik dibandingkan dengan buku yang biasa digunakan siswa. Dalam artikel Fatimah \& A. Widiyatmoko (2014) dinyatakan bahwa hasil penilaian pakar terhadap komik sains dinyatakan layak dengan penilaian pakar media sebesar 95,83\%, pakar materi 95,37\%. Hasil belajar siswa juga meningkat dengan kategori sedang, kemampuan berpikir siswa juga mengalami peningkatan yang signifikan berdasarkan perhitungan $t$ test.

Respon terhadap komik sebagai media pembelajaran ini juga terbilang bagus, hal ini dibuktikan hasil uji lapangan oleh Roby Zulkarnain (2018) juga mendukung hal tersebut yang dapat dilihat dari persentase penilaian respon didapatkan hasil guru sebanyak $86 \%$ dengan respon yang positif dan siswa sebanyak 86,5\%. Menurut Purnama (2015), menggunakan media komik memberikan pengaruh terhadap minat belajar siswa yang lebih tinggi sehingga prestasi belajar siswa pun meningkat dilihat dari nilai rata-rata siswa yang lebih baik dibandingkan hanya dengan menggunakan media gambar sahaja.

Hengkang Bara (2015) menyatakan dalam artikelnya bahwa pembelajaran dengan menggunakan media komik sangat efektif dalam meningkatkan nilai karakter siswa, tanggung jawab dan karakter disiplin siswa dengan nilai gain score sebesar 0,62 atau masuk kedalam kategori sedang. Penelitian terbaru yang sejalan dengan ini juga dilakukan oleh Suparmi (2018) dan menyatakan bahwa dari hasil analisa dapat disimpulkan bahwa penggunaan media komik dapat meningkatkan hasil belajar dan tingginya hasil belajar ini dipengaruhi oleh karakteristik media komik yang digunakan dalam pembelajaran.

\section{SIMPULAN}

Berdasarkan pembahasan dan hasil penelitian di atas maka dapat disimpulkan oleh peneliti bahwa pendekatan saintifik berbantuan komik terbukti dapat meningkatkan hasil belajar, keterampilan berpikir ilmiah, meningkatkan keterampilan berpikir kreatif siswa dan efektif meningkatkan literasi sains siswa.

Media komik juga dapat meningkatkan hasil belajar siswa secara signifikan berdasarkan penelusuran hasil-hasil penelitian terdahulu yang peneliti peroleh. Tidak hanya itu, komik juga menjadi media yang efektif untuk belajar, memahami konsep materi yang abstrak dan mengurangi kebosanan dalam belajar. Pemanfaatan media komik dapat membantu siswa memahami materi IPA dengan cara lebih mudah dan menyenangkan. Komik merupakan media potensial dan efektif untuk pembelajaran IPA karena mempunyai kemampuan dalam memudahkan pembaca untuk memahami dan mengingat isi dari cerita sebagaimana sebuah tampilan video.

Media komik memiliki tokoh atau pemeran sebagai karakter-karakter yang baik di dalamnya. Dengan adanya karakter-karakter baik ini nantinya dapat diabstraksi oleh siswa untuk ditirukan dikehidupan nyata. Dengan demikian, media komik dapat menjadi sarana untuk menanamkan nilainilai positif yang dapat menjadi karakter dalam diri siswa baik itu nilai-nilai kebangsaan, kebhinekaan maupun nilai-nilai keagamaan. Agar pelaksanaan media tersebut berjalan efektif, guru dapat memadukan dengan menggunakan pendekatan saintifik agar siswa dapat terlibat aktif dalam 
pembelajaran. Dengan demikian penggunaan pendekatan saintifik berbantuan komik tidak hanya dapat meningkatkan hasil belajar IPA siswa tapi juga dapat membentuk karakter siswa sehingga mampu memenuhi ketiga aspek penting dalam pendidikan nasional yaitu pengetahuan, sikap, dan keterampilan.

\section{REFERENSI}

Adib Rifqi Setiawan. (2019). Efektivitas Pembelajaran Biologi Berorientasi Literasi Saintifik. Thabiea: Journal of Natural Science Teaching, 02(02), 83-94.

Aprilia, Linda.,\& Sri Mulyaningsih. (2014). Penerapan Perangkat Materi Kalor Melalui Pendekatan Saintifik dengan Model Pembelajaran Guided Discovery Kelas X SMA. Jurnal Inovasi Pendidikan Fisika,2 (2),1-5.

Devy Indah Lestari, \& Anti Kolonial Projosantoso. (2016). Pengembangan Media Komik IPA Model PBL untuk Meningkatkan Kemampuan Berfikir Analitis dan Sikap Ilmiah. Jurnal Inovasi Pendidikan IPA, 2 (2), 2016, 145 - 155

Fatimah, F., \& Widiyatmoko, A. (2014). Pengembangan Science Comic Berbasis Problem Based Learning sebagai Media Pembelajaran pada Tema Bunyi dan Pendengaran untuk Siswa SMP. Jurnal Pendidikan IP A Indonesia, 3(2), 146-153.

Hengkang Bara Saputro, S. (2015). Pengembangan Media Komik Berbasis Pendidikan Karakter Pada Pembelajaran Tematik-Integratif Kelas IV SD. Jurnal Prima Edukasia, 3(3), 61-72.

Johari, Marjan. (2014).Pengaruh Pembelajaran Pendekatan Saintifik Terhadap Hasil Belajar Biologi dan Keterampilan proses sains siswa MA Muallimat NW Pancor Selong Lombok Timur Nusa Tenggara Barat. E-Joumal Program Pascasarjana Universitas Pendidikan Ganesha, Volume 4.

Lailatul Aslamiyah, dkk. (2017). Pengembangan Media Pembelajaran Komik Fisika berbasis Integritas Interkoneksi Nilai-nilai Alquran. Unnes Physics Education Journal. 6(3),45-52.

Nelah Roswati, dkk.(2019). The Development of Science Comic in Human Digestive System Topic for Junior High School Students. Journal of Science Learning. 3(1).12-18.

Niswatul Khoiriyah.(2019). Development comics Physics Education With STEM for Simulating Straight Line Motiom Concept Mastery in Junior Hight School Students. Jurnal Pembelajaran Fisika. 7(2), 77-85.

Permatasari, Eka Aprilia. (2014). Implementasi Pendekatan Saintifik dalam Kurikulum 2013 Pada Pembelajaran Sejarah. Indonesian Journal Of History Education.3(1), 11-16.

Purnama,Unty Bany.,dkk. (2015). Penggunaan Media Komik Digital Dan Gambar Pengaruhnya Terhadap Prestasi Belajar IPA Ditinjau Dari Minat Belajar Siswa. TEKNODIKA. 13 (2),1828.

Roby Zulkarnain.(2018). Pengembangan Komik Pembelajaran pada Materi Bumi dan Alam Semesta untuk Siswa Sekolah Dasar Kelas VI di SDN Utama 2 Tarakan dan SDN 17 Tarakan. Jurnal Bidang Pendidikan Dasar (JBPD), Vol. 2 No. 1 A.

Rudyanto, H. E. (2014).Model Discovery Learning Dengan Pendekatan Saintifik Bermuatan Karakter Untuk Meningkatkan Kemampuan Berpikir Kreatif. Premiere Educandum, 4(31), 41-48.

Sukini.(2019). Penerapan Pembelajaran Guided Inquiry Berbasis Pendekatan Saintifik untuk 
Meningkatkan Aktivitas dan Hasil Belajar Kognitif Biologi Siswa Kelas XI MIPA SMA Negeri 3 Dumai. JNSI: Journal of Natural Science and Integration, 2(1), 105-121.

Suparmi.(2018). Penggunaan Media Komik dalam Pembelajaran IPA di Sekolah. JNSI: Journal of Natural Science and Integration, 4(1), 62-68.

Triandini, E.,dkk. (2019). Metode Systematic Literature Review untuk Identifikasi Platform dan Metode Pengembangan Sistem Informasi di Indonesia. Indonesian Journal of Information Systems (IJIS). vol 1(2).63-77.

Wijayanti, A. (2014). Pengembangan Autentic Assesment Berbasis Proyek Dengan Pendekatan Saintifik Untuk Meningkatkan Keterampilan Berpikir Ilmiah Mahasiswa. Jurnal Pendidikan IP A Indonesia, 3 (2), 102-108. 